science in Hanover College, Ind. It consisted of four pages and the first volume contained only 52 pages of short and mostly local notes. The name of the journal was changed to the Botanical Gazette at the end of the second volume, and M. S. Coulter become one of the editors. In 1883 the editorship was undertaken by the present editors, John M. Coulter, Charles R. Barnes and J. C. Arthur, under whose control the journal has steadily improved up to the present time, when the name of G. F. Atkinson, V. M. Spalding, Roland Thaxter and William Trelease have been added as associate editors. As Dr. Bessey says, the Gazette " has thus been a growth, and it represents to-day much more than so many pages of printed matter. It has grown and developed as the science of botany has grown and developed in this country. When we look over the earlier volumes with surprise at the little notes which fill the pages we must not forget that American botany had not then generally risen above such contributions. It is true that we had a few masters in the science, with Dr. Gray still in his prime, but these masters wrote little for general reading, and their technically systematic contributions were mostly published in the proceedings of learned societies. The one thing which stands out to-day in sharp contrast with the botany of two deeades ago is the very great increase in the number of masters in the science who are making liberal contributions from many different departments. The many-paged Gazette of to-day, with its rich variety of matter, differs no more from the four-page Bulletin of 1876 than does the botany of the two periods."

\section{UNIVERSITY AND EDUCATIONAL NEWS.}

IT is reported by cablegram that Alfred Nobel, the Swedish engineer and chemist, who died at San Remo, Italy, on December 9th, left a will bequeathing his entire fortune, amounting to about $\$ 10,000,000$, to the Stockholm University.

The will of the late Henry L. Pierce, distributes about three and a-quarter million dollars in public bequests, which include $\$ 50,000$ to Harvard University and $\$ 50,000$ to Massachusetts Institute of Technology.

DR. JoHn J. McNulty has been appointed professor of moral and intellectual philosophy in the College of the City of New York.

THE new catalogue of Harvard University shows a registration of 3,674 students, an increase of 74 over last year. There has been a slight decrease in the College, but a gain in the Lawrence Scientific School, in the Graduate School and in the Medical School. There has been an increase of 4 professors and 17 instructors.

At Cambridge University the report of the General Board of Studies, recommending that steps be taken for the immediate appointment. of a professor of mental philosophy and logic, was opposed upon financial grounds and because the establishment of the professorship. was not urgent. The report was, however, adopted, by 120 votes to 70 . The offer of Prof. Sidgwick to reduce his stipend as professor of moral philosophy from $£ 700$ to $£ 500$ per annum. from the time of the appointment of the professor of mental philosophy and logic until midsummer, 1902, or until his chair be vacated, if that should occur before midsummer, 1902, was accepted.

\section{DISCUSSION AND CORRESPONDENCE.}

VAN BENEDEN AND THE ORIGIN OF THE CENTROSOME. -A CORRECTION.

I wIsH to correct an error in my recent book on 'The Cell,' which misrepresents Van Beneden's early views regarding the origin of the centrosomes in the fertilized egg. At page 157 the view, or rather surmise, is attributed to him that, in the fertilization of Ascaris, one centrosome of the first cleavage amphiaster is derived from the egg, the other from the spermatozoon. I am indebted to $\mathrm{my}$ friend, Prof. Conklin, for pointing out that through a miseapprehension of Van Beneden's meaning I am in error on this point. Van Beneden did not, in fact, commit himself to any positive conclusion, but at page 272 of his paper of 1887 expressed the opinion that both attraction-spheres, and hence by implieation both centrosomes, were derived from the egg, $i$. e., from the seeond pseudo-karyokinetic (maturation) figure. Later researches, it is true, have almost conclusively shown that this opinion cannot be sustained; 
but this does not lessen my regret at having unintentionally misrepresented the views of the distinguished leader of cell-research for whose splendid discoveries every investigator must feel such admiration.

\section{Edmund B. Wilson.}

Columbia UnIVERSITY,

New YoRK, December 19, 1896.

\section{THE VELOCITY OF A FLIGHT OF DUCKS OB- TAINED BY TRIANGULATION.}

MeAsurements of the heights and the velocities of clouds are now being made at the Blue Hill Meteorological Observatory by Mr. Rotch as a part of an international scheme for such work. The measurements are made with specially constructed theodolites in which a large conical tube, with crossed wires at one end and an eye-piece at the other, replaces the ordinary telescope.

On the morning of December 8th, while Mr. S. P. Fergusson and I were engaged in measuring clouds, a flock of ducks passed across our base-line, which is 2590.3 metres (8496 feet) in length. We succeeded in getting one simultaneous set of measurements on the apex of the flock from which its height was calculated, and one or two independent subsequent observations, from which the velocity was calculated. The height was 958 feet above the lower station, which is situated in the valley of the Neponset river, above which the ducks were flying.

The velocity of flight calculated from this measurement of height, and from the angular velocity measured at one end of the base-line is 47.9 miles in an hour, and from the angular measurements made at the other end of the base-line is 47.7 miles an hour, making a mean of 47.8 miles. The wind was very light, having a velocity of only two miles an hour according to the automatic record made at Blue Hill Observatory, 615 feet above the valley station. The direction of the wind was from the north, and the ducks were flying from the northeast. These observations were not in our program, but they may prove of interest to ornithologists and students of aëronautics.

H. Helm Clayton.

Blue Hill Meteorological Observatory, Readville; Mass., December 21, 1896.

\section{A TEST ON DIVERSITY OF OPINION.}

To THE Editor of ScIence : It is always interesting to test diversity of opinion, particularly on questions of exact reasoning. It is quite difficult to obtain a test which is at once significant and general. I should be very much indebted to those of your readers who would be willing to send me answers to the following request.

Here is a piece of reasoning which is certainly capable of arousing criticism :

Granted that $A$ is $B$, to prove that $B$ is $A$.

\section{$B$ (like everything else) is either $A$ or not $A$.}

If $B$ is not $A$, then by our first premise, we have the syllogism:

$A$ is $B$;

$B$ is not $A$;

$\therefore A$ is not $A$; which is absurd.

Therefore, $B$ is $A$.

Is this reasoning correct or is it not? If regarded as correct, my request is to have the reasons for its correctness given as explicitly as possible. If it is regarded as incorrect, I wish in the same way a very explicit statement of the nature of the error. Answers are requested from all who are interested in the matter. I am particularly desirous of receiving replies from those whose interest in thought is a philosophical one, as well as from those who are more specially devoted to scientific pursuits.

UNIVERSITY OF WIISCONSIN, Joseph JASTROW.

Madison, WIs., December 5, 1896.

\section{SCIENTIFIC LITERATURE.}

A Geographical History of Mammals. R. LYDEKKER. Cambridge Geographical Series. Cambridge (England) University Press. $8^{\circ}$ pp. 400 , col. map and figures in text. September, 1896. For sale by The Macmillan Company, 66 Fifth Ave., New York City. Price, $\$ 2.60$.

The subject of the geographic distribution of animals is not one to be mastered in a few weeks or months, and many are the pitfalls that lie in wait for the author who seeks to illumine its difficult problems. It is rare, indeed, that a writer in his first essay on this theme suddenly leaps to a position of authority, yet this is precisely what Mr. Lydekker has done. He has approached the subject from a new direction- 